\title{
THE HISTORIAN'S RESPONSIBILITY FOR THE FUTURE: RECORDING COVID-19 FOR THE NEXT GENERATION
}

Joe P. Dunn

Converse College

Articles on Covid-19 are everywhere. I propose a different slant. As a historian with an interest in global politics, I teach students how to view and interpret the past but also how we understand the present in context and how to document the present for the future. The latter is as important as the former. I often pontificate, "Because your grandchildren may ask you about living through an event or time, you need to be attuned to the history being made around you." That history now is Covid-19.

I joke that my life constitutes a living document at center stage of recent history. I have been conscious of that most of my years, and I have recorded and written about my interplay with the more important events of the times-long before I knew the magnitude of them. I was born only days after the end of World War II. I won't claim that I remember that event, but I was at the front edge of the baby boomer generation and all that entailed. I have witnessed a lot of political, social, and cultural change over the decades. I touch on just a few here as demonstration.

An uncle shot down and missing in action in the Korean War hung over family events long after the conflict. Although I was quite young, I heard the secretive, hushed conversations over the rumors that he might still be alive in captivity and about the charlatans who attempted to bilk my aunt to provide her "proof." It began a career-long fascination with POWs about which I have written. During first-grade recess we played war, Chinese Communists vs. Americans rather than cowboys and Indians.

In the fourth grade, I was in one of the first schools to integrate in my state immediately after Brown v. Board of Education, and the first two black students, who lived just across the field in rural Southeast Missouri, got on and off the bus in front of my house. We played together after school. My father was on the school board that integrated the school. From my Arkansas relatives, I heard their somewhat different views on the events at Little Rock Central High School in 1957. In junior high, I cheered the initial black athletes at my high school and played with the next group on the freshman basketball team. I saw in person the segregated eating arrangements on our away-games and even witnessed two high school basketball team lineups-one all-black that started our home games and one all-white for schools that would not accept black athletes at their places. I had some minor roles in desegregation actions during high school.

When I was a college freshman, I knew the first black athlete at my institution because he was from a rival high school. That same year, I remember every detail of the events of the assassination of President John F. Kennedy, which occurred just as I came out of my freshman American history course that Friday afternoon. At the service station where I worked during college, I filled the tank a couple of times for a prominent civil rights activist who stopped there (for the cheapest gas in the region) while coming and going from Mississippi during Freedom Summer 1964.

In my first semester in graduate school, through a wrong exit, I found myself in the center of the protests in East St. Louis following the assassination of the Reverend Dr. Martin Luther King, Jr. And Bobby Kennedy had just visited my undergraduate institution days before his death, where a former girlfriend of the time provided logistics for the visit.

Vietnam interrupted my idyllic life in my Ph.D. program. I thought it an inconvenient and potentially destructive interlude on my way to my academic career. I returned to graduate school planning not to think about Vietnam again. Had I known better, I would have been more astute while there. Partly through the natural instinct as a historian, I did chronicle the experience (for my family) through writing a letter virtually every day that I was not in the field. Thirty years later those letters were the basis of my memoir about the war. I never

(C) 2021 Dunn. Free to copy and share for education and scholarship under a Creative Commons Attribution NonCommercialNoDerivatives 4.0 License. 
thought that I would be teaching the subject, but it came to pass. One of the hard experiences of my academic career was teaching a course on the war in April 1975 on a U.S. Air Force base in Germany while I followed on television the last battle before the Fall of Saigon - at Xuan Loc where I served during the war; I knew the terrain intimately.

As an itinerate professor teaching on military bases in Europe in the mid-1970s, I had Greek students in my class in Athens whose politics changed overnight when dictator Georgios Papadopoulos was deposed. I graded papers on the floor by candlelight in a closed bathroom during blackouts on a Turkish-sovereignty NATO base during the Cyprus War. One of my students, whose plane crash-landed while electronically spying on the conflict, still showed up in class that evening. I was in Spain when General Franco died, and I witnessed the change in mood and atmosphere. I was about ready to announce that if one wanted a dictator gone, just send me into the country. Maybe I should schedule a Russia or China trip.

In Europe, I missed the trauma of the Arab oil boycott in 1973-1974; but back in the U.S. during the 444 days of the American hostages' captivity in the American embassy in Teheran in 1979, the Iranian female student in my class morphed from a Shah apologist to a Khomeini devotee with her wardrobe and hair covering heralding the change. Hair styles and clothing often denote politics. However, the event that ranks among the most painful, both personally and professionally, was $9 / 11$. I walked into their first college class session for my freshmen students in September 2001 minutes after the plane flew into the World Trade Center Tower, and I exclaimed impromptu, "Today a new world began for you that will mark the rest of your life." Inside the Pentagon that day, my brother survived the attack there.

One prays that Covid-19 falls far short of the Influenza Pandemic of 1918-1919. But whatever its length and severity, the Covid period leaves a historical mark. Our department has addressed this historical event in two ways. In academic classes, we offered a freshman honors seminar course this fall on the history of pandemics. My American foreign policy course looked at the impact of Covid-19 globally. I assigned student teams to study national security issues that the new presidential administration would face at the beginning of 2021. Each team was assigned to a specific region and produced a lengthy paper (approximately $40+$ pages) on the major issues to address in their designated region. At various points, the teams conducted briefings, and we held debates between the teams on specific questions. The first briefing for all the teams was on the impact of Covid-19 in their region, placed in historical context. Not surprisingly, in the final reports, Covid-19 ranked as an issue of high concern for each region, and students made policy recommendations on how to address this problem. The quite interesting reports drove home the point of the truly global nature of the issue with implications for policy decisions, particularly how the pandemic might affect actions with countries such as North Korea and Iran.

In my Islamic and Middle East course, one of our topics was the hajj and the transmission of global diseases from the Middle Ages through more recent outbreaks. For this class, I drew on the senior thesis research of one of my students a few years ago, a major in history, politics, and biology. While a student, she presented her paper at an academic conference, and it played a role in securing her present position with the Centers for Disease Control.

These courses in our department draw students from other disciplines, including from healthcare-related fields. Students realized the importance of the study of history for pursuing other areas of inquiry. The approach on this topic and other ventures has resulted in a number of double majors with our department, which is important at a time when selling our major in the current environment is challenging. We are proud to claim a significant number of history majors going to graduate school in policy programs of various types.

Equally, if not more importantly, on the issue of documenting the present, I am having my students, in all my classes, at all levels and majors, write about how Covid-19 has affected their young lives. Other departments should consider this as well to discern possible differences among various majors. The prompt questions are quite simple: Explain how Covid has impacted this year of your college life. For upper-level students, how did college change and how have you reacted to it? What do you think will be the legacy for you from this experience? For freshman students: How is what you have experienced different from how you envisioned the 
college experience? How have you responded? What impact do you see for your future?

Responses vary from terse to lengthy, from sad to humorous. I have not collected enough testimonies yet for anything more than preliminary, brief assessments. For freshmen, clearly it is not what they imagined for their first semester of college. Both class discussions and the first round of essays reveal a degree of frustration, consternation, miasma, and Covid/Zoom fatigue. However, there is not a monolithic viewpoint. Individuals obviously had different experiences. Some politics surface. South Carolina is a very conservative state with a percentage of Covid deniers. It will be interesting to see if responses change as students live with the impositions on their lives for a longer period and if vaccinations and the hopes for an ending time change perceptions. Even the change in presidential administration may affect the results. Finally, does the fact that we are a women's college play a role in responses versus a coed institution? Obviously, this is fertile ground for further analysis, and I hope to write on the subject at a later point when I have more documents.

In any case, I will keep these testaments and deposit copies in the college archives. In my own research, I attest to the great pleasure of discovering an unexpected treasure trove of participant memories. I am reminded of letters my mother wrote when she was a college student during the Great Depression and later on her life during World War II.

But the more important result is that I ask students to save these essays and other remembrances from this experience so that they can reflect on them decades later as first-person documents of the time. This is what being a historian and teaching history is about. We have an obligation to show our students how to think and act like historians on a day-to-day basis and to see the connection between the past, present, and future. The Covid-19 interlude provides a good opportunity, and the possibilities for future research exist. Some military opportunists proclaim, “Don't waste a war; there are benefits to be gained." Less cynically, "Don't waste this pandemic; there is much to be learned." My career mantra to students has been: Live your life, be attuned to it, strive to understand it, and record it for those in the future. This is what historians do. Everyone should. We all have a responsibility for future generations. Students, your grandchildren may thank you, and you might be more cognizant of how your seemingly unextraordinary life fits into history. 